\title{
THE ROLE OF ONLINE AGGREGATORS IN THE VEGETABLE VALUE CHAIN
}

\author{
Janita Meliala"), Musa Hubeis ${ }^{* *}$, Siti Jahroh"**), and Alm. Agus Maulana****) \\ ") Binus Business School \\ Jl. Kyai H. Syahdan No.9, Palmerah, Jakarta Barat, Jakarta 11480, Indonesia \\ ${ }^{* *}$ Department of Management, Faculty of Economics and Management, IPB University \\ Jl. Agatis, Campus of IPB Darmaga Bogor 16680, Indonesia \\ ${ }^{* * *}$ School of Business, IPB University \\ Jl. Pajajaran, Bogor 16151, Indonesia \\ ${ }^{* * * *)}$ Universitas Dr. Soetomo \\ Jl. Semolowaru no 84, Surabaya 60283, Indonesia
}

\begin{abstract}
In Indonesia, many intermediaries of agricultural products are emerging as modern actors called business aggregators who utilize information from the internet or online technologies in their business activities. This study aims to analyze the activities and roles of online aggregators (based on information technology) in the order of value chains of agricultural products, especially vegetables. Purposive sampling technique was used in selecting 12 online business aggregators of vegetable products. Data were obtained through Focus Group Discussions and in-depth interviews with the business aggregator online owner. Based on the results of the analysis show that the main activities of the aggregator business value chain that are divided into three value chains, namely input provider, processing and marketing providers. Online aggregators become important actors in the agribusiness system in the future. In conventional agribusiness systems, non-online aggregators, whose position is in the subsystem, downstream agribusiness, but in online aggregator at present with the advancement of internet, the aggregator is in the middle/middle, between upstream, cultivation, downstream and supporting institutions subsystems.
\end{abstract}

Keywords: intermediaries, online aggregator, vegetable products, value chain

\begin{abstract}
Abstrak: Di Indonesia, banyak perantara modern produk pertanian muncul yang disebut agregator dengan memanfaatkan teknologi internet dalam kegiatan bisnis mereka. Penelitian ini menganalisis rantai nilai aktifitas bisnis agregator komoditas sayuran secara daring di Indonesia. Teknik pengambilan contoh digunakan purposive sampling dalam memilih 12 agregator daring produk sayuran. Data diperoleh Focus Group Discussions dan wawancara mendalam dengan pemilik bisnis online agregator. Berdasarkan hasil analisis menunjukkan bahwa kegiatan utama bisnis agregator dalam rantai nilai produk sayur dibagi menjadi tiga, yaitu penyedia input, pemrosesan dan penyedia pemasaran. Agregator online menjadi aktor penting dalam sistem agribisnis di masa depan. Sistem agribisnis konvensional, agregator posisinya beradada pada subsistem agribisnis hilir, tetapi agregator online saat ini berada di tengah atau antara hulu, budidaya, hilir, dan lembaga pendukung subsistem.
\end{abstract}

Kata kunci: perantara, agregator online, produk sayuran, rantai nilai

${ }^{1}$ Corresponding author:

Email: ycs366@yahoo.com 


\section{INTRODUCTION}

As an economic activity, agriculture can be seen as a system called agribusiness. According to Sjarkowi and Sufri (2004), the definition of Agribusiness is all businesses related to agricultural production activities, which include the operation of agricultural inputs and/or the production of the production itself and the management of agricultural products management. Saragih (2004) also revealed that the agribusiness system includes four subsystems as follows: (1) Upstream agribusiness (up-stream agribusiness), namely industries that produce capital goods for agriculture, such as the seed / nursery industry, plants, livestock, fish, agrochemical industry (fertilizers, pesticides, drugs, livestock vaccines. fish), agricultural equipment and machinery industries (agro-automotive); (2) Primary agricultural sub-system (on-farm agribusiness), which is cultivation activities that produce primary agricultural commodities; (3) Down-stream agribusiness, namely industries that process primary agricultural commodities into processed products such as the food/ beverage industry, feed industry, natural fiber goods industry, pharmaceutical industry, bio-energy industry; and (4) Sub-systems for agribusiness service providers (services for agribusiness) such as credit, transportation and warehousing, R\&D, HR education, and economic policy.

In Indonesia, horticultural products still face problems concerning product distribution chain (Santoso and Darwanto, 2015). The main problem is the inefficiency of the distribution process of horticultural products from producers to end consumers. Due to the small scale of land ownership, the farmers is difficult to obtain the market to get the ideal reward from the risk that they bear, while large profit margins are obtained by intermediaries (Santoso and Darwanto, 2015). Since 2006 in Indonesia modern actors have begun to emerge as intermediaries to sell agricultural products using information communication technology using the internet, which is referred to as an online aggregator in this study. This is an interesting new phenomenon to study, how these online aggregators play a role in the agribusiness system and how online aggregators create value for customers by examining the contribution of different activities in the business to that value as we known as value chain analysis.

Value chain analysis explains the various activities needed to bring products or services from conception, through different production phases (involving a combination of physical transformation and input from various producer services), delivery to end consumers, and final disposal after use (Kaplinsky and Morris, 2003). The concept of agricultural value chains involves various participants (actors) in the moving of agricultural products from input suppliers to farmers' fields and ultimately to consumers. The value chain's main goal is to maximize profits not only by reducing inefficiencies but also by maximizing aggregate revenue for all actors in a particular value chain (FAO, 2014).

Reducing value chain inefficiencies, giving rise to the term disintermediation of value chains. Value chain disintermediation is related to shortening the value chain from producer to consumer (Laudon and Traver, 2017). The role of intermediaries had been reduced due to the use of technologies such as cellular telephones which reduce the interaction of producers with intermediaries and allow farmers to carry out their own distribution processes (Reardon and Timmer, 2012).

Nowadays, there are modern actors who carry out aggregation, sorting, and distribution activities with integrated information technology. The aggregator mentioned in this paper is an aggregator that utilizes information technology (especially the internet).

This aggregator is one who plays a role in the structure of the value chain. Lembong (2016) defines an aggregator as a company or service provider that helps accommodate various kinds of products from sellers, and makes these products available at a place that is easily found by potential customers. The aggregator business model in agriculture was developed by the Africa Working Group (2015) which revealed that the aggregation model benefits are as follows:

a. Logistic support, aggregation reduces logistical costs from smallholder farmers. It may also be a tool for improving quality, as producer organizations can add value to crops through sorting, drying, storing and other functions, depending on their capacity.

b. Marketing and distribution of services, aggregation can reduce marketing, distribution, money-lending and servicing costs for companies selling inputs or financial services to smallholders.

c. Provision of training, training groups to increase productivity are generally more cost-efficient than working with farmers on a one-on-one basis.

d. Information dissemination, aggregation reduces the cost of collecting and disseminating information 
for companies seeking certified crops, by reducing auditing costs for example.

e. Bargaining power, collective action gives farmers bargaining power to secure better prices

Aggregators are basically collectors and intermediaries (Tapsavi, 2009). However, based on the explanation of Africa Working Group, the aggregator does not only play a role as the main actor but also as a service provider in the value chain.

A critical element of the value chain is its governance structure. Governance of value chain refers to the nature of the linkages between actors at particular stages (the elements such as information exchange, price determination, standards, payment mechanisms, contracts with or without embedded services, market power, lead firms, wholesale market systems and so on) (FAO, 2014). Gereffi et al. (2005) put forward value chain governance which shows the flow of material value chains up to the end-user is associated with an explicit level of coordination and strength of asymmetry.

Hence, this study aims to analyze the activities and roles of aggregators (based on information technology) in the order of value chains of agricultural products, especially vegetables. Descriptive research methodology uses value chain analysis by collecting data through in-depth interviews and taking focus group discussion data to 12 online vegetable investment aggregator owners in material and methodology. How the role of bold aggregators in the agribusiness system develops using the information exchange chain in result and discussion.

\section{METHODS}

This study is descriptive research conducted for six months from September 2018 to February 2019. The data were collected through the use of focus group discussions (FGD) as a process of collecting data and information. The focus group technique is a type of qualitative research methodology, defined as a structured and focused discussion with a small group of people, run by a facilitator (moderator) or using a moderating team (Prince and Davies, 2001) to produce qualitative data through a set of open-ended questions. The term focus has an important meaning - it emphasizes that the group will discuss a precise topic of interest rather than broad generalities (Boddy, 2005).
The participants in that FGD following as, 12 founders of online aggregator agriculture products were interviewed (Table 1). Respondents were selected based on a purposive sampling method with the following criteria: 1) aggregators located around the research area (Jakarta, Bogor, Depok, Tangerang, Bekasi, Bandung dan Medan); (2 aggregators who enter the digital farming community.

The FGD was conducted at the Business School of IPB University. FGDs were applied at several stages including:

1. Exploration: the moderator/researcher explained in general about the research topics and important issues that would be the main topics in the FGD. Basically, the researcher has sent preliminary research for FGD participants so already know enough about the topics to be discussed. The moderator has prepared several questions based on the theory about the value chain so that the discussion becomes directed

2. Monitoring: Each FGD was recorded on audiotape. Then, the analysis of the data included a detailed review of all of the typed transcripts and observational notes are taken from the focus group session.

3. Evaluation: At the end or during the phasing-out stage of a research program, an FGD with the main target group can be performed to verify, disprove, modify, or differentiate the study's provisional finding.

4. Assessing outcome: FGD performed to generate new findings.

Table 1. Samples in this research (Founders of Business Aggregator)

\begin{tabular}{ll}
\hline Company name & Website \\
\hline Sayurbox & www.sayurbox.com \\
Kecipir & www.kecipir.com \\
Kedai Sayur & www.kedaisayur.com \\
Etanee & www.etanee.co.id \\
Tanihub & www.tanihub.com \\
Regopantes & www.regopantes.com \\
8Villages & www.8villages.com \\
Sikumis & www.sikumis.com \\
Inagri & www.inagri.asia \\
Pak Tani Digital & www.paktanidigital.com \\
iGrow & www.igrow.asia \\
PT Mandala Agro Persada & www.sayours.co.id \\
Nusantara (Sayours) & \\
\hline
\end{tabular}


Mapping the value chain in this study refers to A Toolbook for Practitioners of Value Chain Analysis developed by the Australian International Centre for Agricultural Research (ACIAR). This research uses an open-ended question, $\mathrm{s}$ for guidelines in determining the dimensions to be mapped, (M4P, 2008) include: Core value chain processes activity; Main actor involved in the value chain; Mapping the product flow; Mapping information flow; Mapping the geography of the product or service; Mapping values added at various levels in the value chain; Mapping services used in the value chain; Mapping the barriers; Create a value chain map matrix.

Besides mapping the value chain, there is a study of certain aspects of the value chain in depth. One of these is cost and margin. In this study, there is limited access to each actor involved in the value chain. So the approach to calculating margins was based on a case study on one of the aggregators by comparing selling prices at each level in the value chain.

$$
M=\frac{\operatorname{Pr}-\mathrm{Pf}}{\operatorname{Pr}} \times 100 \%
$$

Note: M (Margin); Pr (prices at the consumer level); Pf (prices at the farmers' level).

\section{RESULTS}

Based on the results of the FGD, each aggregator explains their business processes based on the dimensions that have been prepared including core activities, actors involved, product flow, information flow, the geography of the product, value-added, services, and barriers.

\section{Core value chain Activities}

The first dimension in the analysis of the value chain is finding out the core activity in the value chain. The core process of this online vegetable aggregator refers to the agribusiness system which consists of the process of providing agricultural inputs, the process of processing agricultural primary products, and the process of marketing agricultural products.

Table 2 shows that in general the main activity of aggregators is the marketing of agricultural products. However, some aggregators carry out processing activities such as Sayurbox and Etanee. The processing of agricultural products is carried out by Etanee aiming that agricultural products that have the characteristics of perishable can last longer by freezing the product and minimally proceeded such as a fresh cut. Aggregator shows that not only accommodates farmers' primary products to be marketed but also accommodates a variety of agricultural input material products, which are distributed to farmers.

\section{Main Actor that Involved}

The second dimension is mapping the actors involved in the value chain. Actors can be categorized based on the main work then place them in categories according to the core processes in the value chain. The main actors involved in this aggregator business are the government, farmers, input/supplier providers, investors/creditors, consumers. The process of providing inputs to the actors involved with the aggregator are suppliers of fertilizers, seeds, agricultural machine tools (agricultural machinery), and capital (investors). Advances in technology encouraging the agricultural input industry to use information technology (internet) in marketing their products. Online aggregators have a role in managing the marketing of agricultural inputs because most farmers use the internet to track prices and access agricultural information services. Aggregators are able to provide information on various choices of agricultural input products and allow farmers to compare and purchase products (Henderson et al. 2002).

Aggregators are not engaged in the cultivation sub-system, but farmers are important partners for aggregators. Aggregators strive to build mutually beneficial relationships. The role of the aggregator is to promote agricultural primary products from farmers, then the aggregator also benefits by carrying out valueadding activities. However, aggregator activities are still faced with obstacles where farmers are fragmented so that they still need the role of local collectors to facilitate the distribution process.

Henderson et al. (2002) revealed that online sales are more common in business-to-business (B2B) than in sales to end-users or customers (B2C). Therefore hotels, restaurants, and offices are the target market for this online aggregator apart from the end consumer. However, some aggregators who process agricultural products require distributors to distribute their products to consumers/customers. 
Table 2. Core activities of the online aggregator business in agriculture

\begin{tabular}{lccc} 
& \multirow{2}{*}{ Aggregator } & \multicolumn{2}{c}{ The core process in the value chain as an intermediary } \\
\cline { 2 - 4 } & Provide input & Processing & Marketing \\
\hline Sayurbox & & $\sqrt{ }$ & $\sqrt{ }$ \\
Kecipir & & & $\sqrt{ }$ \\
Kedai Sayur & & $\sqrt{ }$ \\
Etanee & & & $\sqrt{ }$ \\
Tanihub & $\sqrt{ }$ & $\sqrt{ }$ \\
Regopantes & & & $\sqrt{ }$ \\
8Villages & $\sqrt{ }$ & $\sqrt{ }$ \\
Sikumis & & & $\sqrt{ }$ \\
Inagri & & & $\sqrt{ }$ \\
Pak Tani Digital & & & \\
iGrow & & & \\
PT Mandala Agro Persada Nusantara & & & \\
\hline
\end{tabular}

\section{Product flow mapping}

The third dimension is product flows along the value chain. This activity includes identifying products at each stage of the process, when the product transforms input/production facilities to raw materials, intermediate materials, and becomes the final product. Mapping the flow produces a clear picture of what product forms are handled, changed, and transported at each stage of the process in the value chain. The product flow in the aggregator business cycle can be seen in Figure 1.

Agricultural inputs such as seeds, agricultural equipment and infrastructure, fertilizers, and other input products are marketed through an aggregator. Agricultural inputs such as seeds, agricultural equipment and infrastructure, fertilizers, and other input products are distributed/marketed through an aggregator. Aggregators will more easily market agricultural inputs because of partnering with farmers. Primary products from farmers who partner with aggregators are then marketed through the platform so it can be accessed by unlimited potential customers. However, customers generally consist of business users and retailers, and end consumers.

\section{Information flow}

Invisible aspects of the value chain include information and knowledge. Information mapping includes showing the flow of information between actors in each process in the value chain. Information is a crucial dimension for online aggregators. Information that is important in the value chain includes (1) product prices; (2) market demand (product location and volume); (3) technology; and (4) product/quality specifications. In this case, the important role of the aggregator is managing the flow of information in each level of the value chain.

Product prices are a major issue in the development of online aggregators. The existence of online aggregators makes the price of products both on the consumer and producer sides more transparent because both of them can access the price information on the application services that the aggregator has developed. Other information is related to the amount/volume of market demand. The information held by the aggregator can be used to map the product flow both to find out the number of requests and the number of offers. The aggregator plays a role in managing information related to market demand and distributing this information to farmers in accordance with the location closest to the consumer. Market demand is one of them regarding crop commodities/products that are needed by the market so that farmers not only plant existing plants but adjust to market needs.

In addition, information technology also needs to be distributed to farmers to improve productivity and quality of agricultural products in accordance with consumer desires. Therefore, in general the advantage of the aggregator is its ability to manage information from consumers to be conveyed to producers. 


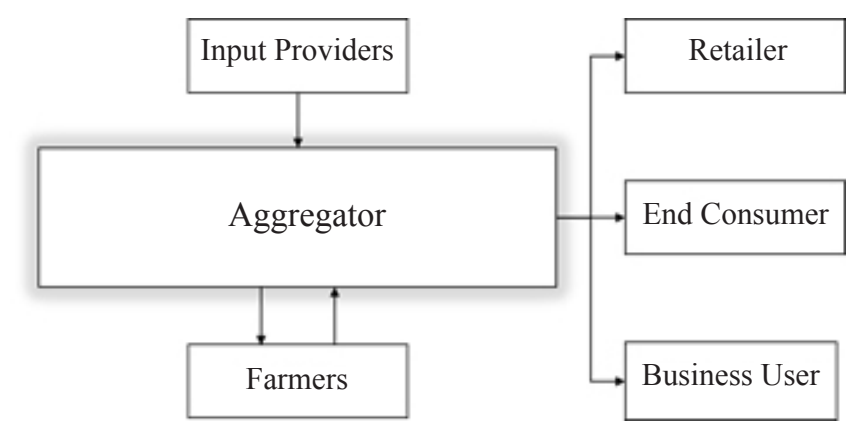

Figure 1. Flow of online aggregator products in agriculture

\section{The geography of the product}

Based on the main activity in the value chain, actors, and product flows, the relative geographic mapping can be directly compiled by following the path of mapped products or services. The use of IT by aggregators encourages the marketing of farmers' products both in cities, outside cities, even abroad. This is because through an application that is developed by aggregators all consumers can access the existence of the product. Currently, the customer of the aggregator is centered in urban areas. Since vegetables are a perishable product, farmers should be located closer to consumers. Vertical farming technology becomes an alternative for people in urban areas who want to farm with limited land.

\section{Value added activities}

Value-added activities carried out by aggregators are processing agricultural products, the process of transporting agricultural products, storing (storing) agricultural products, and the ability to manage information for the marketing process of agricultural products.

The core element of value chain mapping is mapping the value-added along the chain. Kumar and Rajeev (2016) revealed that the value chain focuses on the ability of a company to capture the needs of consumers and its ability to meet those needs for profit. Value is something that can be measured in various ways such as analyzing costs and margins. Mapping value chain analysis obtains accurate information about costs, margins, and profits at various levels of processes in the value chain. This can be by analyzing prices. Figure 2 is the result of value-added analysis seen from the price margins of farmers and end consumers in the case of partner farmers from kecipir.com with chili commodities.

The analysis shows that margins in the presence of online aggregators are higher (88\%) compared to selling to other intermediaries. However, currently, only a small portion of the volume sold to online aggregators. This is because the quantity of requests from online aggregators is relatively less. Online non-aggregator collectors offer relatively lower prices where farmers only get a margin of $35 \%$ with farmers not knowing the selling price of these collectors to end consumers. The reason farmers continue to sell to collectors is that farmers' goods are received without being limited by quantity.

Besides, the advantages of online aggregators are more transparent about the selling price of their products to consumers, because both farmers and consumers can directly access the quantity and price of products on smartphone applications or the website. Other costs are transportation costs borne by the aggregator. Utilization of information technology including information systems in the agricultural sector can increase farmers' incomes (Galtier et al. 2014; Lee and Suzuki, 2015; Delima et al. 2016).

\section{Services provided by the aggregator}

Based on the results of the FGD, the types of services are classified into five services, namely:

\section{Focus on electronic marketing}

Indrajit (2001) revealed that e-commerce has characteristics including transactions between two parties; the exchange of goods, services, or information; the main media in the trading process is the internet.

Overall, the aggregator online utilizes information and communication technology to develop their business based mobile applications or website. Application/ website services make it easy for aggregators to reach consumers more widely. Besides that, this service also reaches out to farmers from various scattered regions. These services help consumers buy farm produce directly from farmers. 


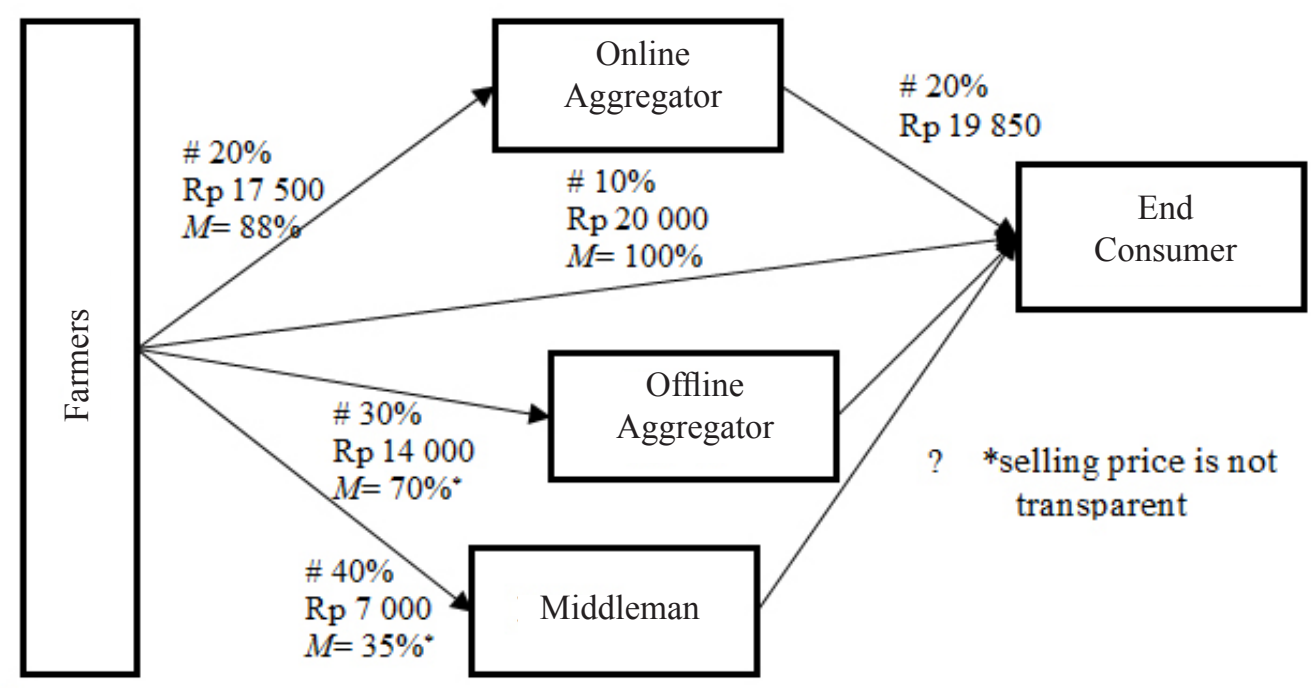

Note: M (Margin); Selling prices per 250gram; * (assuming the consumer purchase price is the same as the farmer's price of selling directly to consumers); \# (percentage of quantities sold by farmers).

Figure 2. Value added at the value chain level (the case of online aggregator farmer partners for chili products)

Two types of online sales are run by aggregators. First, the aggregator sells farmer's products with its brand. Secondly, the aggregator only provides a marketplace platform so that consumers can connect directly with farmers as sellers, only the transaction process is done through an aggregator.

\section{Source of information}

The internet has an instant nature in conveying all forms of information and can be used to deal with the problem of information asymmetry experienced by both producers and consumers regarding availability, price, and product quality (Laudon and Traver, 2017). Therefore, the aggregator business is not just selling farmers' products but can play a role in providing the information needed by farmers in each region.

The characteristics of agricultural products are mostly seasonal, so with the presence of ICT, information related to planting schedules and harvest schedules that are not as simultaneous as each region can be handled by the presence of the aggregator. Singh (2009) revealed that farmers need to review their crop patterns, so farmers can ensure which cropping patterns are most beneficial for farmers. The growth of technological infrastructure can increase internet access both in rural and urban areas, so farmers can access information about plants, weather, inputs, and set prices, and also improve their abilities related to science in agriculture (Singh, 2009). Proper management of information can help farmers make business decisions (Abreu, 2009).

8Villages is one of the aggregators that provide information services for farmers, both concerning prices of agricultural commodities, especially horticulture in the region as well as national average prices, and 8 Villages serve information related to land and development of farmers in each region who have become partners. It provides information and services consultation related to agricultural cultivation issues (such as sustainable agricultural practice).

Sharing information is one of the key factors in the success of the value chain because this factor can increase the confidence of producers (farmers) in producing quality products (Jayantkumar, 2014).

\section{Connectors}

Aggregators can also be referred to as spark-plugs or connectors (Lembong, 2016). Aggregators can reduce inefficiencies in the process of distributing agricultural products. The availability of strong sales information systems producers can dynamically determine the prices of their products to reflect actual demand or it can be said that aggregators play a role in perfectly competitive markets (Lambert, 2012). Sikumis.com 
as an aggregator/connectors provides application/ kiosk services for farmer transaction services using applications that have been designed by the aggregator. This kiosk machine is placed in cooperatives or villageowned enterprises (BUMDes).

Connectors can also play a role in establishing product standardization following the characteristics of the products desired by consumers, so farmers can process their sorting and grading and certainly will increase the selling value of their products (Asokan, 2009; Abreu, 2009; Luqman et al. 2019). While kecipir.com is an aggregator for organic vegetable products, setting standards for organic vegetable products according to consumer desires. Kecipir.com has the desire to create sustainable business by encouraging farmers to apply agriculture without using chemicals (organic farming). Besides, they also have the motivation to provide healthy and quality food (especially vegetables) for their customers.

\section{Community and training}

Farming community is needed as a place for gathering farmers. Increasing rural resource capacity in the village-preneur context improves the village economy and the development of industrial sectors and services. One that develops farming community is 8villages and Pak Tani Digital. 8villages focus on empowering farmers, where they not only provide a way for farmers to market their products but provide training through the farmer communities.

\section{Support provider}

The majority of farmers in Indonesia are small scale, so aggregators can act as providers of input product such as fertilizers, certified seeds, pesticides, agricultural machinery, and farming capital (Singh et al., 2013). There are three type of support provider.

First, providers of physical inputs, such as seeds at the production level or packaging materials at the processing level. Secondly, providers of non-financial services, such as field spraying, storage, transport, laboratory testing, management training, market research and processing. The price offered is competitive, because the aggregator business will seek direct suppliers of the highest quality (for example the sikumis.com aggregator business). Lasindrang and Fauzi (2018) in their research revealed that imported fertilizers are easier to find because products are sold through online stores, while local fertilizer producers still go through offline distribution, which spends more time compared to online distribution.

Then the third is providers of financial services. Crowdfunding is a new term in terms of industrial finance. Crowdfunding emerged as an alternative tool to finance start-up businesses and businesses that were in the expansion phase (Allison et al.2014). Crowdfunding is one of the funding alternatives developed by the aggregator in the agricultural industry such as those managed by TaniHub, Sikumis, and iGrow. This is very useful for the advancement of agriculture in Indonesia, where the funding can be utilized by farmers who are generally not bankable in Indonesia

\section{Provide processing product}

Vegetables are a perishable product, so environmental control factors in post-harvest, processing, and marketing play an important role in maintaining the quality and freshness of vegetables. Therefore we need a special treatment to maintain quality and extend the self-life (shelf life) of vegetables to consumers. Aggregators have a role in overcoming the problems of the perishable product by processing primary products into a finished or secondary products. Etanee has applied to provide processing products such as a frozen product that can delay the decay process of agricultural products.

\section{Barriers}

The aggregator is very dependent on IT progress. At present, the application developed by aggregators is supported by the internet. However, the obstacle experienced by aggregators is internet penetration that has not been distributed in Indonesia, so that coverage of operational areas is limited. Internet penetration is still very low because the development of telecommunications infrastructure is still not optimal. Internet penetration is only $34 \%$, and user distribution is $78.5 \%$ in Java and Sumatra. The government and telecommunications companies are very important for the development of the internet evenly. 
Then, the use of ICT is relatively low among farmers because the farmer's education level is relatively low. Lower levels of education among farmers is one of the factors that inhibit the adoption of new technology (Suprehatin, 2019)

The main obstacle in the aggregator of vegetable products is that the product is perishable, so aggregators need to think about how the vegetable product can remain fresh when consumers receive it.

\section{Value Chain Map Matrix}

Mapping various dimensions of the value chain has been completed, a value chain map matrix is prepared by entering a summary of the main information from the eight dimensions that have been analyzed previously into a value chain map matrix.

There are three value chain mapping pathways in the online-based aggregator business of vegetable commodities starting at upstream, namely providers of inputs, processing, and marketing. Business aggregators as input providers add value to the quality and prices that compete on agricultural machinery, seeds, fertilizers, medicines and provide access to appropriate interest rates for farmers and risk protection in the form of agricultural insurance. Business aggregators as processing add value to quality and price by sorting/ grading, freezing/frozen, packaging, semi-finished materials. Business aggregators as marketers add value to prices by selling farmers' products directly to end consumers or businesses such as hotels, restaurants, cafes, and bringing buyers who need large quantities of certain agricultural/vegetable commodities with farmers in the auction market. All aggregator business activities are conducted online, so that information and transactions can be done openly and widely. An online aggregator value chain map matrix can be seen in Figure 3.

Based on the results of the analysis shows that online aggregators become important actors in the agribusiness system in the future. Conventional agribusiness systems tend to separate the roles of each sub-system, and with the existence of online-based aggregators, each subsystem becomes interconnected. The aggregator acts as a collaborator that connects each subsystem to the agribusiness system. In this case, farmers are not only as suppliers of agricultural products marketed by aggregators but also as aggregator market objects for agricultural inputs.

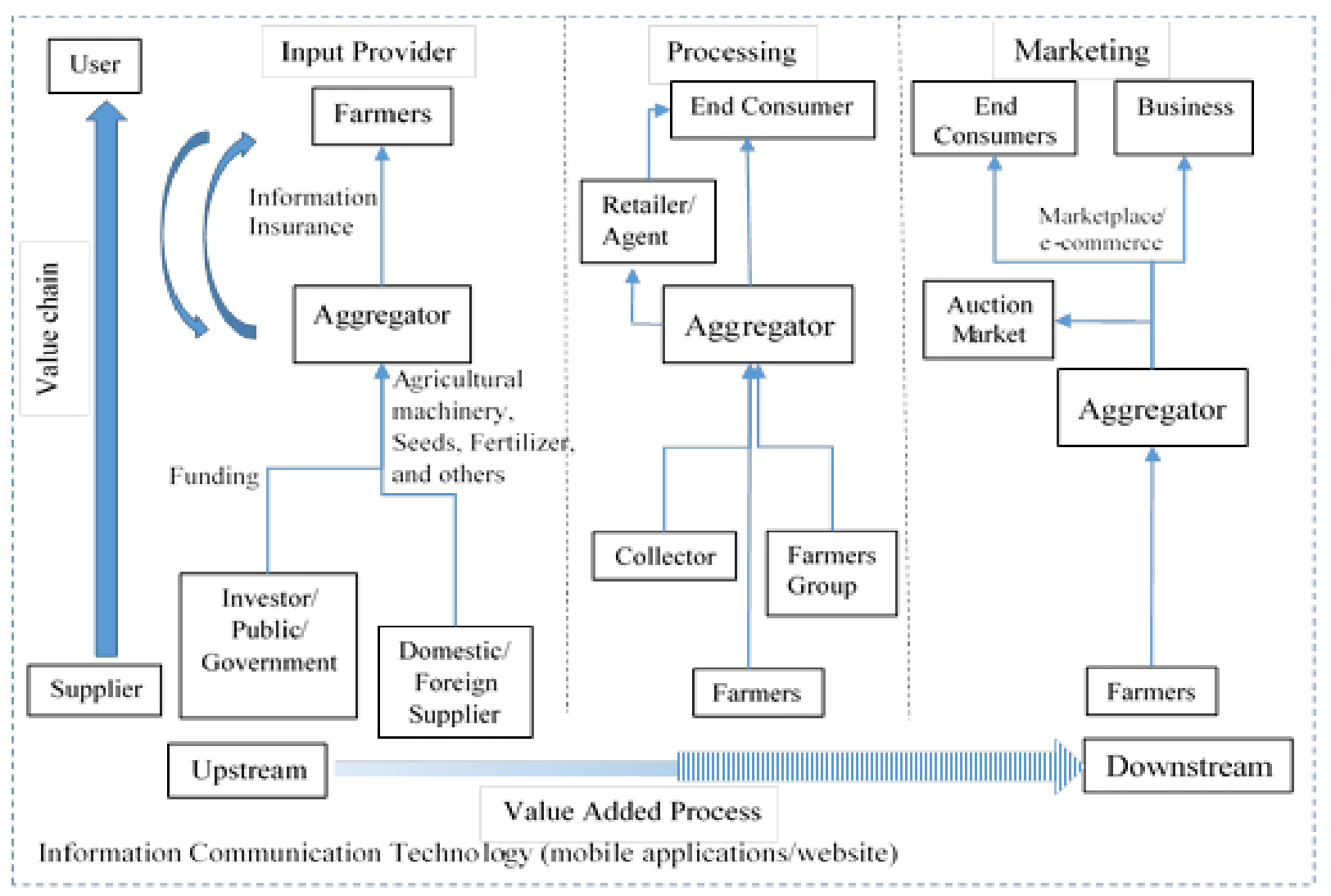

Figure 3. Online aggregator business value chain map matrix 


\section{Managerial Implication}

Based on the results of the value chain analysis, managerial implications can be applied including: 1) Education on the use of internet/information technology, Online aggregators must be able to provide educational services to farmers in utilizing the internet; 2) Infrastructure and network improvements, all activities or services carried out by the aggregator use the internet, but the internet network is not evenly distributed in Indonesia so development needs to be done; 3) Utilization of upstream and downstream technology, this is done to improve the quality and quantity of the product; 4) The motivation of young farmers. The Digital era is an opportunity for young farmers to contribute to the agricultural sector in Indonesia. It is hoped that young farmers will be able to contribute to implementing modern agriculture by creating new social networks and bonds that facilitate cooperation and coordination for mutual benefit.

Theoretically, the conventional agribusiness system includes 4 sub-systems, namely upstream agribusiness, cultivation, downstream agribusiness, and supporting provider. Based on conventional agribusiness systems, the aggregator acts as an intermediary whose position is in the downstream agribusiness subsystem. The results of the analysis related to the role of the aggregator show that the aggregator acts as a collaborator by using information technology in this case the internet to synergize the 4 subsystems so that in the agribusiness system the aggregator becomes the center between the upstream, cultivation, downstream and supporting institutions.

\section{CONCLUSIONS AND RECOMMENDATIONS}

\section{Conclusions}

The value chain map matrix in this study shows that the aggregator is not only in the downstream activities but also in the upstream and support provider activities. There are three types of aggregator business activity in the value chain, namely input provider, processing product, and marketing providers. The strength of online aggregators is their ability to manage the information needed by each actor in the order of the value chain. The success of this aggregator business is also determined by the use of ICTs, including infrastructure and technology acceptance for each participant involved in the order of value chain.

\section{Recommendations}

Current conditions show an increase in people shopping online, especially vegetable products. Quantitative follow-up studies are needed to see the effectiveness of services provided by online aggregators to obtain a dominant variable in decision making. There needs to be a deeper and quantitative study of farmers in general related to farmers' readiness for online aggregators.

\section{ACKNOWLEDGEMENTS}

I would like to thank LPDP (Indonesia Endowment Fund for Education), Ministry of Finance, Republic of Indonesia for taking part in providing me with the financial support to finish this paper.

\section{REFERENCES}

Abreu. 2009. Uttarakhand state cooperative federation: can it help the horticulture farmers?: Case Analysis 4, The Journal of Business Perspective 13(21): 63-68. https://doi. org/10.1177/097226290901300207.

African Working Group. 2015. How do off-takers and smallholder farmers use aggregation models to grow their business ?' (October), 1-7 [online]. Retrieved from: https:/www.grow-africa.com/ resources/how-do-takers-and-smallholderfarmers- use-aggregation-models- grow- theirbusiness.

Allison TH, Davis BC, Short JC, Webb JW. 2014. Crowd funding in a Prosocial Microlending Environment: Examining the Role of Intrinsic Versus Extrinsic Cues. Entrepreneurship Theory and Practice 39: 53-73. https://doi.org/10.1111/ etap. 12108.

Asokan. 2009. Uttarakhand state cooperative federation: can it help the horticulture farmers?: Case Analysis 2, The Journal of Business Perspective 13(21): 64-66. https://doi. org/10.1177/097226290901300207.

Boddy C. 2005. A rose by any other name may smell as sweet but group discussion\| is not 
another name for a focus groupl nor should it be. Qualitative Market Research: An International Journal 8(3): 248-255. https://doi. org/10.1108/13522750510603325.

Delima R, Santoso HB, Purwadi J. 2016. Kajian aplikasi pertanian yang dikembangkan di beberapa negara Asia dan Afrika. Seminar Nasional Aplikasi Teknologi Informasi (SNATi) 2016 [Internet]; 2016 Ags 6; Yogyakarta, Indonesia. Yogyakarta: Universitas Islam Indonesia. hlm 19-26.

[FAO] Food and Agriculture Organization. 2014. Developing sustainable food value chains Guiding principles. Rome: FAO.

Galtier F, Benz HD, Subervie J, Egg J. 2014. Agricultural market information sistems in developing countries: New models, new impacts. Cahiers Agricultures 23: 232-244. https://doi. org/10.1684/agr.2014.0716.

Gereffi G, Humphrey J, Sturgeon T. 2005. The governance of global value chains. Review of International Political Economy 12(1): 78-104. https://doi.org/10.1080/09692290500049805.

Indrajit RE. 2001. E-commerce: kiat dan strategi bisnis di dunia maya. Indonesia: PT Elex Media Komputindo.

Jayantkumar PH. 2014. Key success factors of dairy value chain in Gujarat: an empirical study. International Journal Value Chain Management 7(2):153-170. https://doi.org/10.1504/ IJVCM.2014.062929.

Kaplinsky, R. and Morris, M. 2003. A Handbook for Value Chain Research, International Development Research Centre (IDRC), Canada

Kumar D, Rajeev KV. 2016. Value chain: a conceptual framework. International Journal of Engineering and Management Sciences 7(1):74-77.

Lambert Q. 2012 Business models for an aggregator. [thesis]. Information Management \& Computer Security.

Lasindrang LFY, Fauzi ADH. 2018. Hubungan distribusi terhadap penjualan (studi pada distribusi pupuk npk non subsidi area pemasaran Kalimantan di PT. Pupuk Kalimantan Timur). Jurnal Administrasi Bisnis. 54(1): 197-206.

Laudon KC, Traver CG. 2017. E-Commerce 2017Business, Technology, Society. US: Pearson.

Lee G, Suzuki A. 2015. Evaluating the impact of market information sistem on coffee producers': Revenues and profits in Ethiopia [Internet]. [diunduh tanggal 2019 Jan 25] Retrieved from: https://editorialexpress.com/
Lembong T. 2016. Konsep dasar agregator. [article]. Info Perdagangan Dalam Negeri.

Luqman M, Yaseen, M, Ashraf S, Mehmood, MU, Karim M. 2019. Factors influencing use of information and communication technologies among farmers in Rural Punjab, Pakistan. Journal of Agricultural Extension 23(2):101112. https://doi.org/10.4314/jae.v23i2.11.

[M4P] Making Markets Work Better for the Poor. (2008), Making Value Chains Work Better for the Poor: A Toolbook for Practicioners of Value Chain Analysis, Version 3. UK Departement for International Development (DFID). Agricultural Development International: Phnom Penh, Cambodia.

Prince M, Davies M. 2001. Moderator teams: an extension to focus group methodology. Qualitative Market Research International Journal (4): 207-216. https://doi.org/10.1108/ EUM0000000005902.

Reardon T, Timmer CP. 2012. The Economics of the Food System Revolution. The Annual Review of Resource Economics 4(14): 1-40. https://doi. org/10.1146/annurev.resource.050708.144147.

Santoso PB, Darwanto. 2015. Strategi Penguatan Kelompok Tani dengan Penguatan Kelembagaan. Jurnal Ekonomi Pembangunan 16(1): 33-45. https://doi.org/10.23917/jep.v16i1.936.

Saragih B. 2004. Pembangunan pertanian dengan paradigma sistem dan usaha agribisnis. https:// pse.litbang.pertanian. go.id ind/pdffiles/An jak_2004_VI_01.pdf

Singh. 2009. Uttarakhand state cooperative federation: can it help the horticulture farmers?: Case Analysis 3', The Journal of Business Perspective 13(21): 66-68. https://doi. org/10.1177/097226290901300207.

Singh OP, Singh PK, Singh HP, Singh R, Khim RK. 2013. A value chain analysis of vegetables: A case study of Palpa District, Nepal. Economic Affairs 58(2): 135-146

Sjarkowi F, Sufri M. 2004. Manajemen Agribisnis. Palembang: Baldal Grafiti Press.

Suprehatin. 2019. Characteristics of farmer adopters of high value horticultural crops in Indonesia. Jurnal Manajemen \& Agribisnis 16(2): 181190.

Tapsavi SK. 2009. Uttarakhand state cooperative federation: can it help the horticulture farmers?: Case Analysis 1. The Journal of Business Perspective 13(21): 63-64. 